\title{
Latitudinal Variation into the Macrofaunal Assemblages Associated to Zostera noltei Seagrass along the Atlantic Coast of Morocco
}

\author{
Oussama Bououarour (iD, ${ }^{1}$ Soilam Boutoumit (iD, ${ }^{1,2}$ Reda El Kamcha ${ }^{(D)}{ }^{1}$ \\ and Hocein Bazairi $\mathbb{D}^{1,3}$ \\ ${ }^{1}$ Biodiversity, Ecology and Genome Laboratory, Plant and Microbial Biotechnology, \\ Biodiversity and Environment Research Center, Faculty of Sciences, Mohammed V University in Rabat, Rabat, Morocco \\ ${ }^{2}$ University of Nantes, LETG UMR 6554, Nantes, France \\ ${ }^{3}$ Institute of Life and Earth Sciences, University of Gibraltar, Europa Point Campus, Gibraltar GX11 1AA, UK
}

Correspondence should be addressed to Oussama Bououarour; oussama.bouarour@gmail.com

Received 6 July 2021; Revised 14 September 2021; Accepted 17 September 2021; Published 18 October 2021

Academic Editor: Marco Cucco

Copyright (C) 2021 Oussama Bououarour et al. This is an open access article distributed under the Creative Commons Attribution License, which permits unrestricted use, distribution, and reproduction in any medium, provided the original work is properly cited.

\begin{abstract}
Large-scale research on seagrass-associated benthic fauna is very important for future regional marine conservation. In our study, we investigated spatial and latitudinal variation of benthic macroinvertebrate assemblages associated to Zostera noltei Hornemann, 1832 beds from five semi-enclosed coastal systems (SECSs) ranging from $23^{\circ} \mathrm{N}$ to $34^{\circ} \mathrm{N}$ along the Atlantic coast of Morocco. Overall, 17,320 individuals were reported as belonging to 96 taxa. The ecological community descriptors differ significantly at the level of the site. Specific richness showed an inconsistent significant pattern with latitude. The multivariate analyses of the assemblage's composition showed $57 \%$ of total variation observed in benthic assemblages, while the PERMANOVA analysis confirmed that this variation is significant at the level of the site. According to DistLM results, variations in belowground biomass, and percentage of mud, were the important predictor variables explaining this variation along the large scale of the studied SECS. However, such patterns could be related to other factors such as habitat heterogeneity and regional, biogeographic, and anthropogenic factors. The present study marked the first attempt on broadscale ecological research of seagrass beds in Morocco and offers baseline data for planning the broad-scale conservation of biodiversity in seagrass beds that remain suffering from multiple human-induced threats such as coastal developments and climate change.
\end{abstract}

\section{Introduction}

Changes in the composition of community or species assemblages have been and continue to be the subject of intense interest. Anthropogenic pressures and the need for effective conservation planning have further inspired the study of diversity patterns and processes at regional and global scales [1]. Ecologists have been interested in the global pattern of biodiversity for a long time [2], and the comprehension of the distribution of life on the earth is the major goal of ecology and biogeography [3]. The latitudinal diversity gradient (LDG) is one of the most outstanding ecological patterns on our planet. It is generally defined as an increase in species richness from the poles towards the equator and is a striking ecological pattern that has fascinated biologists over centuries [4]. The main drivers behind the LDG are focused on theories that are broadly linked to the current climate, historical effects, and biome area $[5,6]$.

The latitudinal gradient of diversity is well defined in different taxonomic groups and many geographical regions $[7,8]$, whereas land diversity patterns and their predictors are known for numerous taxa [9], and our understanding of global marine diversity has been more limited, with recent findings revealing some striking contrasts to widely held terrestrial paradigms [10]. Besides, the similarity of species composition is probable to decline with distance because variations in environmental conditions generally upsurge with the distance between regions [11]. 
Seagrass has a wide geographic distribution and presence, except in Antarctica, in many shallow coastal and oceanic waters around the world [12]; therefore, related population and community processes can be compared on a wide spatial scale [13]. They support abundant and generally well-known macrofauna, the density and diversity of which also surpass the existing in nearby bare sediment fields $[14,15]$.

The existence of seagrass meadows in coastal ecosystems favors the establishment and preservation of a high diversity of species in benthic communities [16] which are suitable organisms to test latitudinal patterns as they respond very well to environmental changes and have a high diversity [17]. Seagrass beds and associated invertebrates provide various valuable ecological services including coastal conservation and erosion prevention, carbon sequestration, fisheries maintenance, water purification, and the supply of raw materials and food [18]. However, the quantitative estimation of population and community variables over broad spatial scales is lacking for seagrass-associated communities.

The dwarf eelgrass Zostera noltei Hornemann, 1832 is the dominant seagrass in the Atlantic semi-enclosed coastal systems (SECSs) of Morocco. It is considered globally as one of the most important perennial seagrass species on intertidal mudflats [19]. It is widely distributed on the Atlantic, from Norway south to the Mauritanian coast, and present in the Mediterranean, the Black Sea, and even in the Caspian and Aral Sea [20]. The existence of $Z$. noltei with no doubt contributes significantly to the biological, ecological, and environmental values of these SECSs, which are most included in the Ramsar List [21].

At the same time, global seagrass beds are declining at a remarkable rate [22]. Zostera noltei is one of the few seagrass species that are adapted to the hard conditions of the intertidal habitat [23]. However, in semi-enclosed coastal areas, this species is most susceptible to impacts resulting from climate change and anthropogenic stresses [24]. Benthic species patterns have rarely been investigated at once on the entirety of the Moroccan coastline (from $20^{\circ} \mathrm{N}$ to $35^{\circ} \mathrm{N}$ ). Indeed, the existing studies had only a limited geographical scope (Merja Zerga lagoon [25]; Oualidia Lagoon [26]; and Khnifiss Lagoon [27]).

In this study, by comparing benthic macrofauna assemblages in five SECSs along the Atlantic coast of Morocco, with consideration of the positions in each SECS (downstream and upstream), we investigated whether there is a latitudinal pattern of benthic macrofauna associated with $Z$. noltei habitats of Moroccan SECSs. Then, we determined the main environmental factors that could drive to the patterns of distribution and diversity of benthic assemblages. We hypothesized that (1) specific diversity increases towards low latitude along the Moroccan Atlantic coast and (2) that there is a variation in the benthic assemblages among sites and between seagrass positions.

\section{Materials and Methods}

2.1. Study Sites. Benthic macrofauna associated to Zostera noltei beds were sampled from five SECS distributed along the Atlantic Moroccan coastline: four lagoons: Merja Zerga,
Sidi Moussa, Oualidia, and Khnifiss and one bay: Dakhla (Figure 1).

The Merja Zerga lagoon $\left(34^{\circ} 47^{\prime} \mathrm{N}-6^{\circ} 13^{\prime} \mathrm{W}\right)$ is an elliptical-shape lagoon with a depth from 0.50 to $1.50 \mathrm{~m}$. It occupies an area of about $30 \mathrm{~km}^{2}$, and it is largely influenced by tidal rhythms ranging nearly $1.4 \mathrm{~m} \mathrm{[28]}$. It is submitted to several pressures such as cattle raising, artisanal fishing, shell-fishing, and tourism [29].

The Sidi Moussa lagoon $\left(32^{\circ} 52^{\prime} \mathrm{N}-8^{\circ} 51^{\prime} \mathrm{W}\right)$ covers an area of $4.2 \mathrm{~km}^{2}$ with a maximum depth of approximately $5 \mathrm{~m}$, which decreases progressively towards the upstream part of the lagoon. The tidal regime is semidiurnal with a tidal level varying between 2 and $4 \mathrm{~m}$ [30]. In the lagoon, various activities such as traditional fishing and aquaculture have a considered impact [31].

The Oualidia lagoon $\left(34^{\circ} 47^{\prime} \mathrm{N}-6^{\circ} 13^{\prime} \mathrm{W}\right)$ is over $7 \mathrm{~km}$ long and $1 \mathrm{~km}$ wide, with a mean depth of $2 \mathrm{~m}$ for a total surface of $3 \mathrm{~km}^{2}$. It is characterized by a semidiurnal tide and entrances ranging from $0.8 \mathrm{~m}$ to 3.6 [32]. The lagoon is subject to various stressors related to fishing activities, aquaculture, and algae exploitation [33].

The Khnifiss lagoon $\left(28^{\circ} 02^{\prime} \mathrm{N}-12^{\circ} 13^{\prime} \mathrm{W}\right)$ is located at the southern coastal Sahara, and it extends for about $20 \mathrm{~km}$ in length, $5 \mathrm{~km}$ width for a total surface of $65 \mathrm{~km}^{2}$, and a maximum depth of $8.7 \mathrm{~m}$ [34]. The tidal regime is semidiurnal, and it ranges between a minimum of $1.48 \mathrm{~m}$ downstream to a maximum of $2.54 \mathrm{~m}$ inside the lagoon. In the lagoon, few fishing activities are present [35].

The Dakhla Bay $\left(23^{\circ} 35^{\prime} \mathrm{N}-15^{\circ} 50^{\prime} \mathrm{W}\right)$ extends over $37 \mathrm{~km}$ length and $12 \mathrm{~km}$ width for a total surface of $400 \mathrm{~km}^{2}$ and separated from the ocean on its south extremity through a wide $13 \mathrm{~km}$ pass [36]. It is a mesotidal system ranging between 0.5 and $2.5 \mathrm{~m}$ and with a total depth of no more than $20 \mathrm{~m}$. With the expansion of the harbor, navigation channel dredging, the bay has higher environmental and ecological concerns [37].

2.2. Sampling and Analysis. Our sampling was based on a comparison of two seagrass meadows, one downstream and one upstream in each of the five sites between December 2014 and January 2015. In each of the two meadow positions, three stations were randomly sampled (10 replicates per station) in the central dense area of the seagrass bed using a hand PVC corer of $12.5 \mathrm{~cm}$ diameter to a depth of $20 \mathrm{~cm}$. The 10 replicates per station totalize a surface of $0.12 \mathrm{~m}^{2}$ per station. Samples were sieved using a mesh of $1 \mathrm{~mm}$ and then fixed and conserved with formalin (4\%) with Rose Bengal for coloration.

Each sample of benthic macrofauna was associated with a sample of sediment collected for the determination of organic carbon and grain-size analyses. The hydrological parameters (water temperature, $\mathrm{pH}$, and salinity) were also measured in situ using a HANNA portable multiparameter. For $Z$. noltei meadow characterization, three replicates, using the same hand PVC corer as mentioned above, were sampled and were carefully rinsed on site with seawater to remove remaining inorganic particles and conserved in plastic bags until preparation for analysis. 


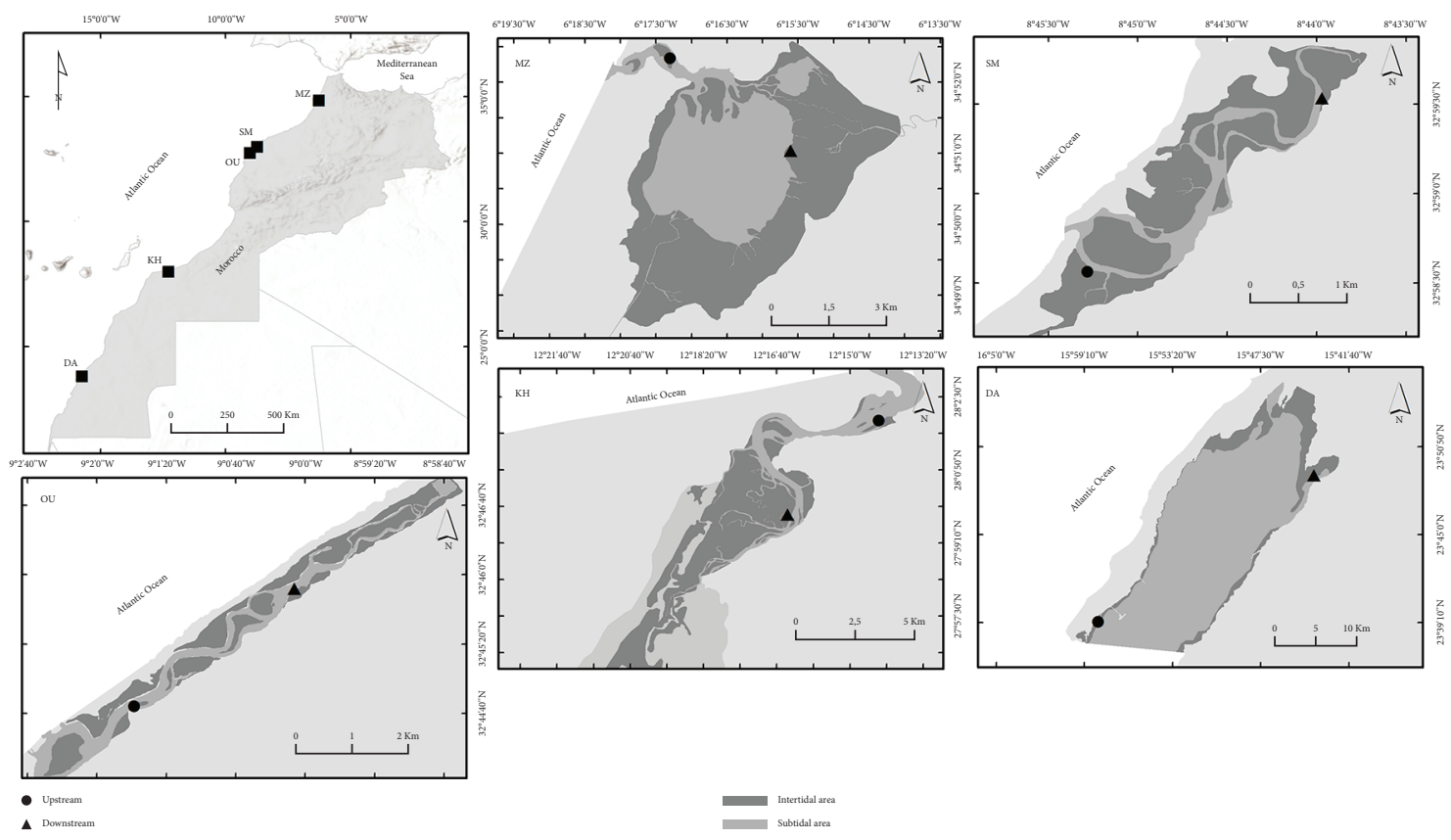

Figure 1: Map showing the location of the study sites across the Atlantic coast of Morocco. MZ: Merja Zerga lagoon; SM: Sidi Moussa lagoon; OU: Oualidia lagoon, KH: Khnifiss lagoon, and DA: Dakhla Bay.

Macrofauna was sorted, identified (to the species level when possible), counted, and preserved in ethanol (70\%). The scientific names and the systematic order of species were revised and updated following the WoRMS database (http://marinespecies.org/). Biomass (B) (AFDW, ash free dry weight) was determined following desiccation $(48 \mathrm{~h}$ at $60^{\circ} \mathrm{C}$ ) and calcination in the oven at $500^{\circ} \mathrm{C}$ for $3 \mathrm{~h}$.

Sediment samples were used for the determination of the different fraction ratios [38]. The grain size was measured using a laser granulometer (Malvern Mastersizer 2000) at LETG, UMR 6554, University of Nantes. Its complete distribution is then treated with the Gradistat ${ }^{\odot}$ Excel package $[39,40]$. To increase the precision of the organic matter estimation, a $\mathrm{LECO}^{\odot}$ carbon analyzer estimates the $\mathrm{CO}_{2}$ and $\mathrm{CaCO}_{3}$ percentages after a $1400^{\circ} \mathrm{C}$ dioxygen burning and a mineral decarbonizing with a sulfuric acid solution [41, 42].

Additionally, three replicates per station of Zostera noltei beds were randomly sampled for seagrass characterization: shoot density (nb shoots $/ \mathrm{m}^{2}$ ), aboveground biomass (gDW/ $\mathrm{m}^{2}$ ), and belowground biomass $\left(\mathrm{gDW} / \mathrm{m}^{2}\right)$. Samples of $Z$. noltei were cleaned and separated into leaves and belowground parts (roots and rhizomes) and then were ovendried at $60^{\circ} \mathrm{C}$ until constant dry weight (DW).

Abundance $\left(N\right.$ : Ind. $\left./ \mathrm{m}^{2}\right)$, number of species $(S)$, Shannon-Wiener diversity index $\left(H^{\prime}, \log _{2}\right)$, and Pielou's evenness index $\left(J^{\prime}\right)$ were calculated for each sample using The DIVERSE routine. A two-way analysis of variance (ANOVA), according to the two-factor (site and position) design, was used to test the differences on $S, N, B, H^{\prime}$, and $J^{\prime}$ at different scales. Post hoc pairwise multiple comparisons were performed using the Tukey test whenever the interaction between effects showed significant differences $(p<0.05)$. Correlations between these ecological indicators with latitude were tested to determine their pattern along the large gradient.

Benthic faunal abundance data were averaged from the three replicates per station. After a fourth root transformation to downweigh the importance of high-abundance species, similarities between sampling stations were calculated using a Bray-Curtis similarity coefficient and then interpreted with the SIMPROF similarity profile test. Environmental variables were $\log (x+1)$ transformed and normalized, and a resemblance matrix was created using the Euclidean distance [43]. To visualize differences in overall community structure, Principal Coordinates Ordination (PCO), based on the Bray-Curtis dissimilarity matrix, was performed, as it is considered one of the most suitable visual complements to PERMANOVA output [44], and species that were correlated (Pearson $\rho>0.5$ ) to sample ordination were represented as superimposed vectors in the PCO graph. Differences between sites and positions were tested with a two-way crossed PERMANOVA design, with the site (random factor, with six levels) and position (fixed factor, two levels) being used as factors in the design [45]. The SIMPER routine (cutoff 50\%) was used to identify the species most contributing to the similarity of each identified assemblage and the dissimilarity among them [46].

Before all statistical analyses, the environmental data were evaluated by draftsman plots to determine collinearity. Tests for collinearity were conducted with no measured collinearity among the environmental parameters (all values $<0.95$ ), and hence, all variables were retained for possible inclusion in the model. We performed a distance-based linear model permutation test (DistLM) to identify which set of environmental variables predicted the multivariate variation in macrofauna assemblages. The adjusted $R^{2}$ was used as a selection criterion to permit the fitting of the best 
explanatory environmental variables in the model. Euclidean distance was used as the resemblance measure in all DistLM procedures. Results were visualized using the graphical representation of the distance-based redundancy analysis (dbRDA).

All the abovementioned procedures were performed with the PRIMER $6+$ PERMANOVA $^{\circledR}$ software (software package from Plymouth Marine Laboratory, UK) [43, 47], while the two-way ANOVA among benthic community structure indexes was carried out in the Statistica software package (StatSoft Inc., 2011, version 10).

\section{Results}

3.1. Environmental Variables. Values of environmental parameters are shown in Table 1 . The mean temperature is ranging from 14.06 to $21.38^{\circ} \mathrm{C}$ with a clear variation between upstream and downstream samples. $\mathrm{pH}$ values were different between sites in both positions with a variation among position areas. Salinity values present a significant variation beyond sites ranging from 16.25 to 39.75 . The sediment composition revealed that the mud content is varying from 8.00 to $88.43 \%$ in the sampling sites. Concentration of $\mathrm{CO}_{2}$ and $\mathrm{CaCO}_{3}$ showed a significant difference among sites $(p<0.05)$ with no difference between downstream and upstream samples.

For seagrass measurements, shoot density ranged from 2194 to 6250 shoots. $\mathrm{m}^{-2}$, while aboveground biomass was varying between 56.4 and $146.1 \mathrm{~g} \mathrm{DW} \mathrm{m}^{-2}$ and the belowground biomass was fluctuating from 22.8 to $223.9 \mathrm{~g} \mathrm{DW} \mathrm{m}^{-2}$. All the seagrass parameters did not present a significant difference at the level of position (downstream/upstream) $(p>0.05)$, while at the level of sites, only the belowground biomass was significantly different $(p<0.05)$. The Pearson correlation between latitude and all the abovementioned environmental variables revealed a significant relationship between temperature $(r=-0.672)$, shoot density $(r=-0.716)$, and belowground biomass $(r=-0.931)$ (Table 2$)$.

3.2. Diversity and Species Composition. This study identified a total of 17,320 individuals belonging to 96 benthic macroinvertebrate taxa. At the level of the phylum, the Zostera noltei beds in the sampled SECS were highly dominated by crustaceans with 38 species, representing more than $38 \%$ of the sampled macrofauna. The mollusks were composed of 24 species representing $33 \%$ of the total of individuals followed by the polychaetes with nearly $25 \%$ of the abundance belonging to 27 species. The other phyla (platyhelminths, nemerteans, echinoderms, and cnidarians) were far less abundant with $3.18 \%$ of the mean global abundance with only seven species.

Taxonomic richness reached the maximum values in the Dakhla downstream sample (DA-D) $(31 \pm 3)$, and the lowest mean abundance was recorded in the Merja Zerga downstream site (MZ-D) $(11 \pm 1)$. Density ranged from $2361 \pm 264$ individuals per $\mathrm{m}^{2}$ in Oualidia upstream samples (site OU-U) to $9464 \pm 902$ individuals per $\mathrm{m}^{2}$ in the Merja Zerga downstream site (MZ-D). Biomass was greater in Merja Zerga upstream (MZ-U) with $244.5 \pm 48.7 \mathrm{~g}$ AFDW m$^{-2}$, while the lowest biomass values were noted in Khnifiss downstream samples (KH-D) $\left(1.31 \pm 0.1 \mathrm{~g} \mathrm{AFDW} \mathrm{m}^{-2}\right.$ ) (Table 3).

Taxonomic richness $(S)$, abundance $(N)$, biomass $(B)$, Shannon's diversity index $\left(H^{\prime}\right)$, and Pielou's evenness $\left(J^{\prime}\right)$ were significantly different at the level of sites (Table 4). Post hoc analyses showed that all these descriptors' values are increasing significantly from Merja Zerga lagoon to Dakhla Bay. However, at the level of position, the only descriptor that did not show a significant difference was the biomass. Interactions between the two effects showed significant differences for $N, H^{\prime}$, and $J^{\prime}$ (Table 4). The mean species richness of benthic macrofauna from all the stations investigated in the present study decreased with latitude $(R=-0.76$; $p=0.01$ ) (Figure 2). The other ecological descriptors did not show a significant correlation with latitude.

3.3. Latitudinal Patterns of Benthic Assemblages. PERMANOVA analysis showed significant and independent differences in the structure of macrofauna for site ( $p$ perm $<0.05)$, while there was no significant difference in terms of position ( $p$ perm $>0.05)$. The interaction between effects was significant ( $p$ perm $=0.0001$ ) (Table 5).

SIMPER analysis showed that the species contributing the most to the average similarity within group I $(60.51 \%)$ were the two mollusks Peringia ulvae Pennant, 1777 and Scrobicularia plana da Costa, 1778, the polychaete Heteromastus filiformis Claparède, 1864, and the isopod Idotea chelipes Pallas, 1766; group II (56.36\% of average similarity) is characterized by the presence of the gastropod $P$. ulvae, three bivalves (Cerastoderma edule Linnaeus, 1758, S. plana, and Abra tenuis Montagu, 1803), the crustaceans I. chelipes and Microdeutopus chelifer Spence Bate, 1862, the polychaete $H$. filiformis, and the cnidarian Actinia equina Linnaeus, 1758. Group III (63.52\% of average similarity) is dominated mainly by crustacean species, two isopods (Cyathura carinata Krøyer, 1847 and I. chelipes), and two amphipods (Lysianassa ceratina Walker, 1889 and Melita palmata Montagu, 1804) with the contribution of the polychaetes (Cirriformia tentaculata Montagu, 1808, Aphelochaeta sp. Blake, 1991, and Diopatra sp. Audouin and Milne Edwards, 1833). Finally, group IV was defined by four crustaceans (C. carinata, I. chelipes, M. chelifer, and Urothoe elegans Spence Bate, 1857) and five polychaetes (Euclymene palermitana Grube, 1840, H. diversicolor, Scoloplos armiger Müller, 1776, Nicomache (Loxochona) trispinata Arwidsson, 1906, and H. filiformis) (Table 6).

The dissimilarity between group I and the other groups (G II, 56.86\%; G III, 79.33\%, and G IV 76.03\%) was mainly due to the dominance of the gastropod $P$. ulvae and the amphipod $M$. chelifer. The main responsible taxa of dissimilarity of group II with other groups were A. tenuis, C. edule, C. carinata, M. palmata, and Ampithoe ferox Chevreux, 1901. The species Leucothoe richiardii Lesson, 1865, Aphelochaeta sp., and Terebella lapidaria Linnaeus, 1767 are the main contributors in the dissimilarity of group III with the other groups. Likewise, the dissimilarity-contributing taxa between group IV and the other assemblages were the crustaceans Ampelisca sp Krøyer, 1842, Apseudes 


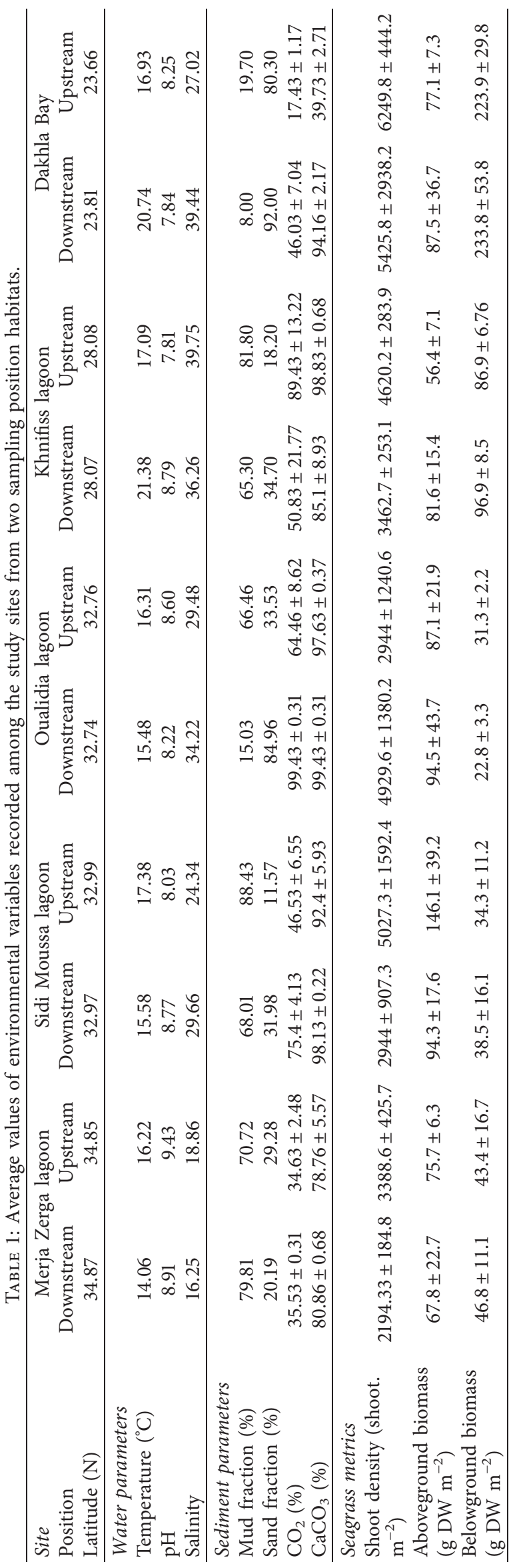


TABle 2: Pearson's correlation coefficients $(r)$ for the relationships between latitude and each of the environmental variables used for this study.

\begin{tabular}{lc}
\hline & Correlation with latitude $(\mathrm{N})$ \\
\hline Temperature $\left({ }^{\circ} \mathrm{C}\right)$ & $\mathbf{- 0 . 6 7 2}$ \\
$\mathrm{pH}$ & 0.598 \\
$\mathrm{Salinity}$ & -0.631 \\
$\mathrm{Mud}(\%)$ & 0.601 \\
$\mathrm{CO}_{2}(\%)$ & 0.222 \\
$\mathrm{CaCO}_{3}(\%)$ & 0.404 \\
Shoot density (shoot. $\left.\mathrm{m}^{-2}\right)$ & $\mathbf{- 0 . 7 1 6}$ \\
Aboveground biomass $\left(\mathrm{g} \mathrm{DW} \mathrm{m}^{-2}\right)$ & 0.218 \\
Belowground biomass $\left(\mathrm{g} \mathrm{DW} \mathrm{m}^{-2}\right)$ & $\mathbf{- 0 . 9 3 1}$
\end{tabular}

Bold values mean that significative correlations based on $p<0.05$ were detected for the tested parameter.

sp. Leach, 1814, Caprella acanthifera Leach, 1814, and $U$. elegans, with $N$. trispinata and S. armiger (Table 7).

The first two axes of the PCO analyses explained 57\% of total variation, and the PCO plot indicated a distinct pattern of the benthic communities' structure between the "northern" and the "southern" site's samples (Figure 3). They were clearly separated along the $\mathrm{PCO}_{1}$ axis (37.4\%) which is negatively correlated with $C$. tentaculata $(r=-0.83)$, Chone duneri Malmgren, 1867 ( $r=-0.72)$, Ampithoe ramondi Audouin, $1826(r=-0.91)$, and Ampelisca sp. $(r=-0.64)$ and correlated positively with $A$. tenuis (0.68), while the $\mathrm{PCO}_{2}$ axis $(19.6 \%$ of total of variation) separating between groups in both regions is negatively correlated positively with Bittium reticulatum da Costa, 1778 ( $r=0.61)$, Capitella capitata Fabricius, 1780 $(r=0.66)$, Ampelisca sp. $(r=0.67)$, Apseudes sp. $(r=0.63)$, and negatively with Aphelochaeta sp. $(r=-0.72)$.

\subsection{Relationship between Environmental and Biological Data.} The sequential DistLM analysis showed that the belowground biomass of the seagrass, the salinity, and the percentage of mud fraction in the sediment had a significant correlation on the latitudinal distribution of benthic assemblages $(p<0.05)$, explaining the greatest proportion $(63 \%)$. However, the best solution provided through the DistLM analysis was found when using five variables (salinity, temperature, percentage of mud, aboveground, and belowground biomasses) as environmental predictors of benthic macrofauna composition, explaining $78 \%$ of the total variability between samples (Table 8). The first two dbRDA axes captured $69.8 \%$ of the variability in the fitted model and $54.6 \%$ of the total variation in the data cloud (Figure 4$)$. The first dbRDA1 axis (36\% of the total variation) is correlated with belowground biomass $(r=-0.71)$ and \% salinity $(r=-0.46)$. The dbRDA2 axis represents $18.6 \%$ of the total variation and correlated strongly with the percentage of mud $(r=-0.61)$ and salinity $(r=-0.6)$ (Figure 4$)$.

\section{Discussion}

Latitudinal diversity gradient, peaking in the tropics and declining near the poles, forms the most remarkable largescale biotic pattern common for both marine and terrestrial systems. Several studies conducted at the regional scale (1000 s of $\mathrm{km}$ ) have reported a significant change in benthic communities along a latitudinal scale $[48,49]$. These changes refer mostly to major effects, such as the proximity of upwellings, variation in water temperature, and the anthropic disturbances $[50,51]$.

Previously, latitudinal comparisons of benthic community structure consider literature reviews and qualitative work [52]. The insufficiency of existing quantitative baselines on this scale limits our ability to assess if changes in these habitats are varying naturally or a result of anthropogenic influence or a mixture of both. Boutoumit et al. [53] found no relationship between latitude and species richness and taxonomic diversity by compiling checklist data considering 12 SECSs along the Moroccan coast which include our studied sites. Our work provides a structured quantitative characterization of Zostera noltei beds in the semienclosed benthic ecosystems on the Atlantic coast of Morocco.

This study revealed diverse benthic macrofauna for the Zostera noltei beds with overall 96 taxa, and crustaceans had the highest abundance compared to the other benthic fauna such as mollusks and annelids. This finding was in line with the results of a study conducted by Tanner [54], which stated that crustaceans were the most abundant group of fauna living in seagrass ecosystems. Comparison of mean species richness with previous studies was difficult because of variance of the sampling design (core dimensions, number of replicates, and number of selected sites). However, given the number of sampling size used in this analysis, the $Z$. noltei beds of our studied sites (96) were less than those recorded on the same ecosystem in the Kneiss Islands, Tunisia (148), and Arcachon Bay, France (117) [55]. The less diverse $Z$. noltei beds reported in the different studies where the seagrass is annual [56] or shows large annual fluctuations due to the grazing pressure by $\mathrm{mi}-$ grating seabirds (Table 9).

The macrofaunal diversity appears to be a more significant structural parameter varying across the sites [57]. It is the most elementary parameter employed by studies examining the large-scale variation of biodiversity and frequently reveals a linear relationship with latitude $[58,59]$. Our results state that the species richness of benthic communities associated with $Z$. noltei was highly variable across the study sites. These results agree with many existing macroecological studies that showed that richness overall decreased with increasing latitude [60].

The multivariate analyses of assemblage's composition showed a $57 \%$ of total variation observed in benthic assemblages, with the presence of species that are omnipresent in all sites such as C. edule, C. carinata, I. chelipes, and $H$. diversicolor. On the contrary, some species were present in just one site (e.g., Lekanesphaera rugicauda Leach, 1814 in Merja Zerga lagoon, Caprella acanthifera Leach, 1814, and Caprella takeuchii Guerra-García, Sánchez-Moyano, and García-Gómez, 2001 in Dakhla Bay). This similar pattern of restrictedness of the species has been stated elsewhere [58]. Furthermore, the PERMANOVA analysis confirmed that faunal assemblages changed significantly among sites. 


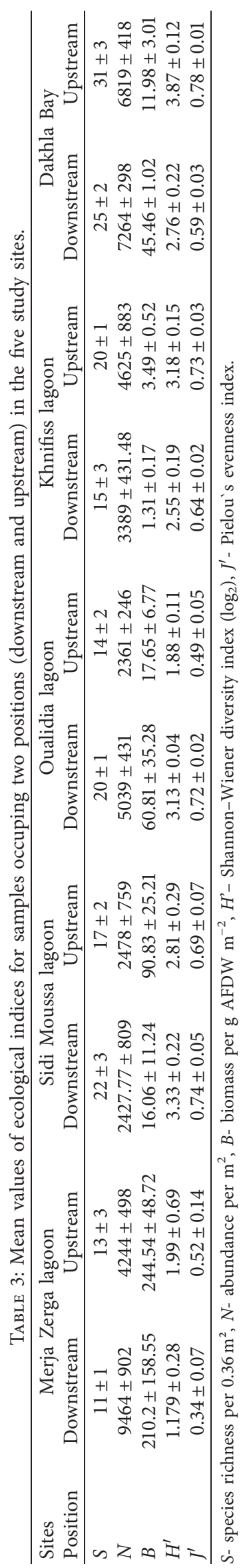




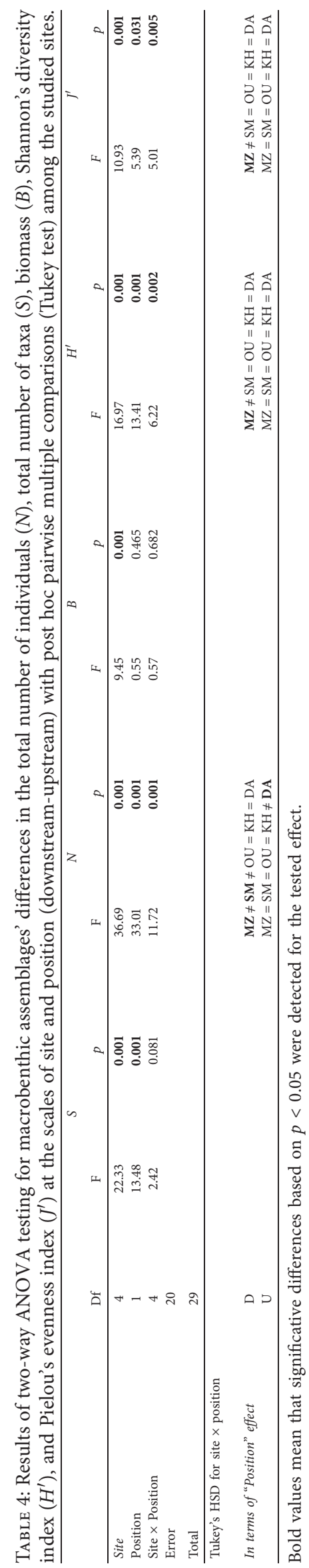




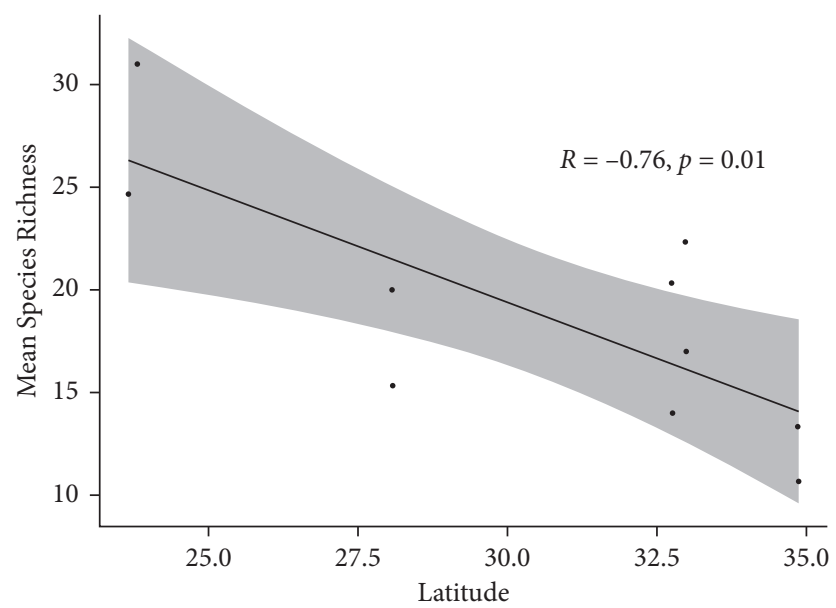

Figure 2: Pearson's correlation analyses of mean species richness of Z. noltei beds present in the sampled sites with latitude. Samples were collected from downstream and upstream stations of five semi-enclosed coastal ecosystems along the Atlantic coast of Morocco. Grey shaded area: 95\% confidence intervals of best-fit lines.

TABLE 5: Results of the multivariate permutational analysis (PERMANOVA) for benthic assemblages considering "site" (5 levels, random) and "position" (2 levels, fixed) factors. Analyses are based on Bray-Curtis similarity matrixes from fourth root transformed data; $\mathrm{Df}=$ degrees of freedom; $\mathrm{MS}=$ mean square; and $p($ perm $)=$ level of significance.

\begin{tabular}{|c|c|c|c|c|}
\hline Source & df & MS & Pseudo-F & $p($ perm $)$ \\
\hline Site & 4 & 10809 & 18.702 & 0.001 \\
\hline Position & 1 & 5246.4 & 1.1611 & 0.367 \\
\hline Site $\mathrm{x}$ position & 4 & 4518.3 & 7.8178 & 0.001 \\
\hline Residual & 20 & 577.94 & & \\
\hline Total & 29 & & & \\
\hline \multicolumn{5}{|c|}{ Pairwise comparisons for the term site $\mathrm{x}$ position } \\
\hline \multicolumn{5}{|c|}{ For pairs of levels of "site" within the level of "position" } \\
\hline$D^{1}$ & \multicolumn{4}{|c|}{$\mathbf{M Z} \neq \mathbf{S M}=\mathrm{OU} \neq \mathbf{K H} \neq \mathbf{D A}$} \\
\hline$U$ & \multicolumn{2}{|c|}{$\mathrm{MZ} \neq \mathrm{SM} \neq \mathrm{OU} \neq \mathrm{KH} \neq \mathrm{DA}$} & & \\
\hline
\end{tabular}

Bold values mean that significative differences based on $\mathrm{p}<0.05$ were detected for the tested variable.

TABLE 6: Results of SIMPER analysis showing the average similarity within the different benthic assemblages. Assemblages were identified by the hierarchical ascendant classification analysis and the characteristic species of each benthic assemblage.

\begin{tabular}{|c|c|c|c|c|}
\hline Groups & G I & G II & G III & G IV \\
\hline Average similarity (\%) & 60.51 & 56.36 & 63.52 & 53.11 \\
\hline \multicolumn{5}{|l|}{ Species contribution, \% } \\
\hline Abra tenuis & & 6.89 & & \\
\hline Actinia equina & & 6.60 & & \\
\hline Aphelochaeta sp. & & & 6.53 & \\
\hline Cerastoderma edule & & 7.09 & & \\
\hline Cirriformia tentaculata & & & 8.35 & \\
\hline Cyathura carinata & & & 10.48 & 5.64 \\
\hline Diopatra sp. & & & 6.35 & \\
\hline Euclymene palermitana & & & & 7.16 \\
\hline Hediste diversicolor & & & & 5.79 \\
\hline Heteromastus filiformis & 13.08 & 2.75 & & 5.10 \\
\hline Idotea chelipes & 10.70 & 7.64 & 7.23 & 5.37 \\
\hline Lysianassa ceratina & & & 7.97 & \\
\hline Melita palmata & & & 6.41 & \\
\hline Microdeutopus chelifer & & 1.91 & & 5.61 \\
\hline Nicomache (Loxochona) trispinata & & & & 5.37 \\
\hline Peringia ulvae & 17.60 & 8.83 & & \\
\hline Scoloplos armiger & & & & 5.48 \\
\hline Scrobicularia plana & 13.77 & 6.96 & & \\
\hline Urothoe elegans & & & & 5.44 \\
\hline
\end{tabular}

Bold values refer to the highest contributive species on the similarity in each benthic assemblage. 
TABLE 7: Results of SIMPER analysis showing the average dissimilarity between the different benthic assemblages. Assemblages were identified by the hierarchical ascendant classification analysis and the species contributing in the dissimilarity of each benthic assemblage (cutoff 50\%).

\begin{tabular}{|c|c|c|c|c|c|c|}
\hline $\begin{array}{l}\text { Groups } \\
\text { Average dissimilarity (\%) }\end{array}$ & $\begin{array}{c}\text { G I and G II } \\
56.86\end{array}$ & $\begin{array}{c}\text { G I and G III } \\
73.22\end{array}$ & $\begin{array}{c}\text { G I and G IV } \\
76.03\end{array}$ & $\begin{array}{c}\text { G II and G III } \\
67.04\end{array}$ & $\begin{array}{c}\text { G II and G IV } \\
72.71\end{array}$ & $\begin{array}{c}\text { G III and G IV } \\
66.01\end{array}$ \\
\hline \multicolumn{7}{|l|}{ Species contribution, $\%$} \\
\hline Abra tenuis & 3.60 & & & 3.87 & 2.78 & \\
\hline Actinia equina & 4.23 & & 3.09 & 2.36 & & 2.60 \\
\hline Ampelisca sp. & & & 3.02 & & 2.86 & 3.12 \\
\hline Amphitoe ramondi & & & 2.78 & & 2.62 & \\
\hline Ampithoe ferox & 3.76 & & & 2.78 & 2.03 & \\
\hline Aphelochaeta sp. & & 3.81 & & 3.66 & & 2.87 \\
\hline Apseudes latreillii & & & & & 1.51 & \\
\hline Apseudes sp. & & & 2.54 & & 2.42 & 2.64 \\
\hline Bittium reticulatum & 2.15 & & & & & \\
\hline Caprella acanthifera & & & 3.49 & & 3.27 & 3.57 \\
\hline Caprella takeuchii & & & & & 1.65 & 1.80 \\
\hline Cerastoderma edule & 3.12 & & & 2.49 & 1.73 & \\
\hline Chone duneri & & & 1.91 & & 1.57 & 1.67 \\
\hline Cirriformia tentaculata & & 4.38 & & 4.21 & 1.54 & \\
\hline Clibanarius erythropus & 2.49 & & & & & \\
\hline Cyathura carinata & 3.88 & & & 4.78 & 2.23 & \\
\hline Diopatra sp. & & 4.13 & 3.23 & 3.97 & 3.06 & \\
\hline Dynamene sp. & & & & & 1.53 & \\
\hline Euclymene palermitana & 3.13 & & 3.59 & 2.32 & 1.71 & 3.71 \\
\hline \multicolumn{7}{|l|}{ Hediste diversicolor } \\
\hline Heteromastus filiformis & 3.70 & 5.19 & & 2.26 & & 2.40 \\
\hline Lysianassa ceratina & 3.05 & 4.65 & & & 1.62 & 3.51 \\
\hline Lekanesphaera rugicauda & 3.56 & & 1.98 & & & \\
\hline Leucothoe richiardii & & 2.92 & & 2.79 & & 2.17 \\
\hline Loripes orbiculatus & & & 1.85 & & & \\
\hline Lagis koreni & 2.69 & & & & & \\
\hline Melita palmata & 2.58 & & & 2.23 & 1.64 & 1.68 \\
\hline Microdeutopus chelifer & 4.51 & 3.62 & 3.38 & & 1.56 & \\
\hline Nicomache (Loxochona) trispinata & & & 2.72 & & 2.57 & 2.80 \\
\hline Ophiura sp. & & 2.95 & 1.81 & & & \\
\hline Peringia ulvae & 4.46 & 8.39 & 6.10 & 4.98 & 3.55 & \\
\hline Sabella spp. & & & & 2.43 & & 1.91 \\
\hline Scoloplos armiger & & & 2.36 & & 2.35 & 3.06 \\
\hline Scrobicularia plana & & 2.80 & 3.81 & & 2.56 & 1.84 \\
\hline Tanais dulongii & & 2.72 & & & & 2.05 \\
\hline Terebella lapidaria & & 5.18 & & 4.95 & & 2.87 \\
\hline Tritia pfeifferi & & & & & & 1.68 \\
\hline Urothoe elegans & & & 3.06 & & 2.89 & 3.16 \\
\hline
\end{tabular}

Such variations in benthic macrofaunal composition over a large scale could rise from the supposition that each habitat has its unique characteristics, which recommend an individualistic approach to ecosystem ecology. Certainly, all habitats are vulnerable to environmental and climatic influences, and their variations generate a response from populations [61]. Diversity and spatial heterogeneity of species can be affected by ecological and evolutionary processes at local and regional levels [62], the systemic variability of transitional waters [63], and the resultant distribution of the benthic macrofaunal organisms according to their functional features and niche demands [64].

According to DistLM results, variations in belowground biomass, salinity, and percentage of mud explained a larger part of the variation in benthic fauna than other abiotic parameters within the studied systems. Indeed, the presence of seagrass influences the macrofaunal diversity and biomass [65] and the biomass of seagrass affects the organization of benthic macrofaunal assemblages [66]. Moreover, variations might be related to substrate type and organic residues [67].
The studied semi-enclosed ecosystems are subjected to different anthropogenic disturbances. Boutahar et al. [68] have showed a clear variation on chemical elements accumulated by $Z$. noltei leaves along the North-South latitudinal scale of the Atlantic coast of Morocco. Differences in anthropic pressures and environmental conditions do not only exist between sites but also between upstream and downstream stations within the semi-enclosed systems. Furthermore, they are situated along a widespread gradient of climate regimes (semiarid and arid) and hydrological (e.g., temperature and salinity) conditions. The absence of a clear pattern with latitude means that the natural mechanisms that can affect diversity across sites are mostly the same along this stretch of the Moroccan coast. We support the postulate that other different processes, operating at different spatial scales, may explain the latitudinal trends in diversity $[9,69]$. Southern systems (Khnifiss and Dakhla) exhibited the highest specific richness and composition variability which can be related to the strong hydrodynamic conditions ensuring the homogenization of water masses and their fast renewal rate. It is also linked with the absence 


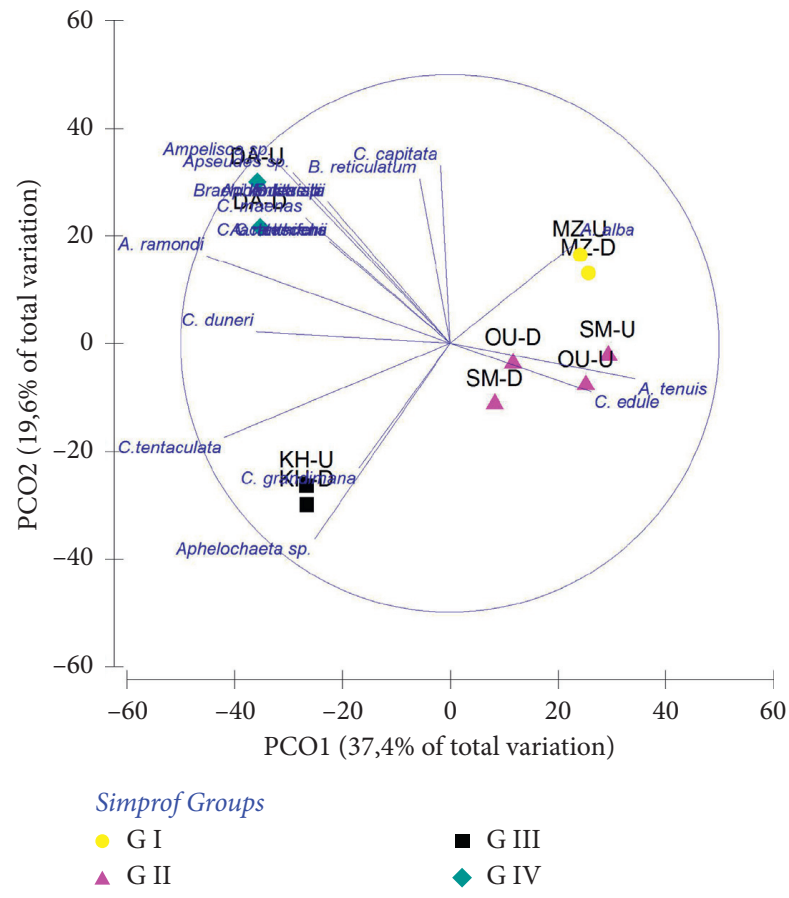

FIGURE 3: Principal coordinate analysis (PCO) of benthic fauna mean abundance data of sampled sites. Attributes that were most associated to the PCO axes (Person correlations $>0.3$ ) are represented by vectors that overlap the PCO.

TABLE 8: Results of the sequential test of the multivariate regression analysis (DistLM). Environmental variables were analyzed individually (marginal test) and sequentially using a forward selection procedure (adjusted $R^{2}=$ an information criterion).

\begin{tabular}{lcccc}
\hline Variable & Pseudo-F & $p$ value & Proportion & Cumulativeproportion \\
\hline Belowground biomass & 3.8336 & $\mathbf{0 . 0 0 0 4}$ & 0.3239 & 0.3237 \\
Salinity & 2.6418 & $\mathbf{0 . 0 0 8 3}$ & 0.1852 & 0.5092 \\
Percentage of mud & 2.068 & $\mathbf{0 . 0 4 7 4}$ & 0.1258 & 0.6350 \\
Aboveground biomass & 1.2697 & 0.2882 & 0.0739 & 0.7089 \\
Temperature & 1.3613 & 0.2605 & 0.0739 & 0.7828 \\
\hline
\end{tabular}

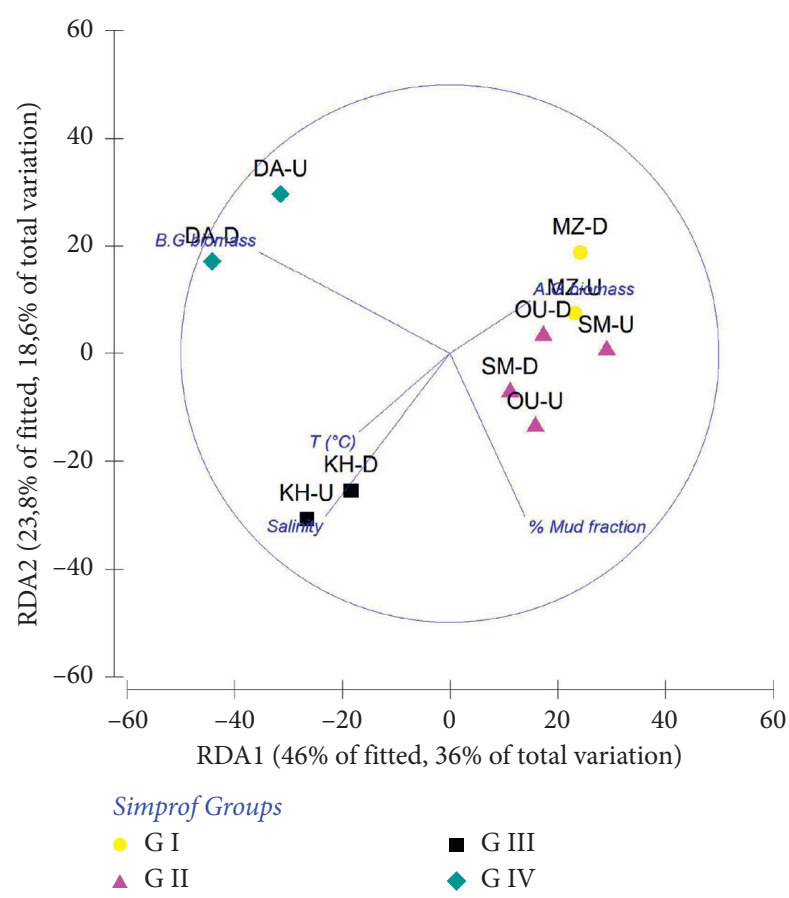

Figure 4: Two-dimensional distance-based redundancy analysis (dbRDA) ordination representing the model of spatial variation in macrofaunal community structure related to the predictor variables selected through the best linear models based on distance (DistLM). 
TABLE 9: List of the taxa found in Zostera noltei beds in the study sites.

\section{Phylum \\ Cnidaria}

Nemertea

Platyhelminthes

Annelida

Arthropoda

Class/order

Taxa

Actinia equina (Linnaeus, 1758) Nemertea spp.

Platyhelminthes spp. Minot, 1876 Aphelochaeta sp. Blake, 1991 Aphrodita sp. Linnaeus, 1758

Capitella capitata (Fabricius, 1780)

Chone duneri Malmgren, 1867

Cirriformia tentaculata (Montagu, 1808)

Diopatra sp. Audouin and Milne Edwards, 1833

Diopatra neapolitana Delle Chiaje, 1841

Euclymene palermitana (Grube, 1840)

Glycera tridactyla Schmarda, 1861

Hediste diversicolor (O.F. Müller, 1776)

Heteromastus filiformis (Claparède, 1864) Lagis koreni Malmgren, 1866

Lumbrineris latreilli Audouin and Milne Edwards, 1833 Magelona sp. F. Müller, 1858

Marphysa sanguinea (Montagu, 1813)

Naineris laevigata (Grube, 1855)

Nephtys hombergii Savigny in Lamarck, 1818

Nicomache (Loxochona) trispinata Arwidsson, 1906 Notomastus latericeus Sars, 1851

Owenia fusiformis Delle Chiaje, 1844 Phyllodoce sp. Lamarck, 1818 Sabella spp. Linnaeus, 1767

Scoloplos armiger (Müller, 1776) Spio sp. Fabricius, 1785

Streblospio shrubsolii (Buchanan, 1890) Syllides sp. Örsted, 1845

Terebella lapidaria Linnaeus, 1767 Ampelisca sp. Krøyer, 1842

Ampithoe ferox (Chevreux, 1901) Ampithoe ramondi Audouin, 1826 Caprella acanthifera Leach, 1814 Caprella grandimana Mayer, 1882

Caprella takeuchii Guerra-García, Sánchez-Moyano, and García-Gómez, 2001 Corophium sp. Latreille, 1806 Elasmopus rapax Costa, 1853

Amphipoda Ericthonius punctatus (Spence Bate, 1857) Gammarella fucicola (Leach, 1814) Leptocheirus hirsutimanus (Spence Bate, 1862) Leucothoe sp. Leach, 1814

Leucothoe richiardii Lessona, 1865

Lysianassa ceratina (Walker, 1889) Melita palmata (Montagu, 1804)

Metaphoxus simplex (Spence Bate, 1857)

Microdeutopus chelifer (Spence Bate, 1862)

Urothoe elegans Spence Bate, 1857 Iphinoe serrata Norman, 1867 Iphinoe trispinosa (Goodsir, 1843)

Cumacea nitescens (Leach, 1814 (in Leach, 1813

Carcinus maenas (Linnaeus, 1758)

Clibanarius erythropus (Latreille, 1818)

Decapoda

Hippolyte sp. Leach, 1814 (in Leach, 1813-1815) Pagurus sp. J.C. Fabricius, 1775 Palaemon elegans Rathke, 1836

Processa sp. Leach, 1815 (in Leach, 1815-1875) Upogebia pusilla (Petagna, 1792) Cyathura carinata (Krøyer, 1847)

Dynamene edwardsi (Lucas, 1849) Dynamene sp. Leach, 1814 Idotea chelipes (Pallas, 1766)

Isopoda

Tanaidacea phaera levii (Argano and Ponticelli, 1981)

Lekanesphaera rugicauda (Leach, 1814) Apseudes sp. Leach, 1814

Apseudopsis latreillii (Milne Edwards, 1828)

Chondrochelia savignyi (Kroyer, 1842)

Tanais dulongii (Audouin, 1826)

Chironomidae larvae Dolichopodidae larvae 
TABle 9: Continued.

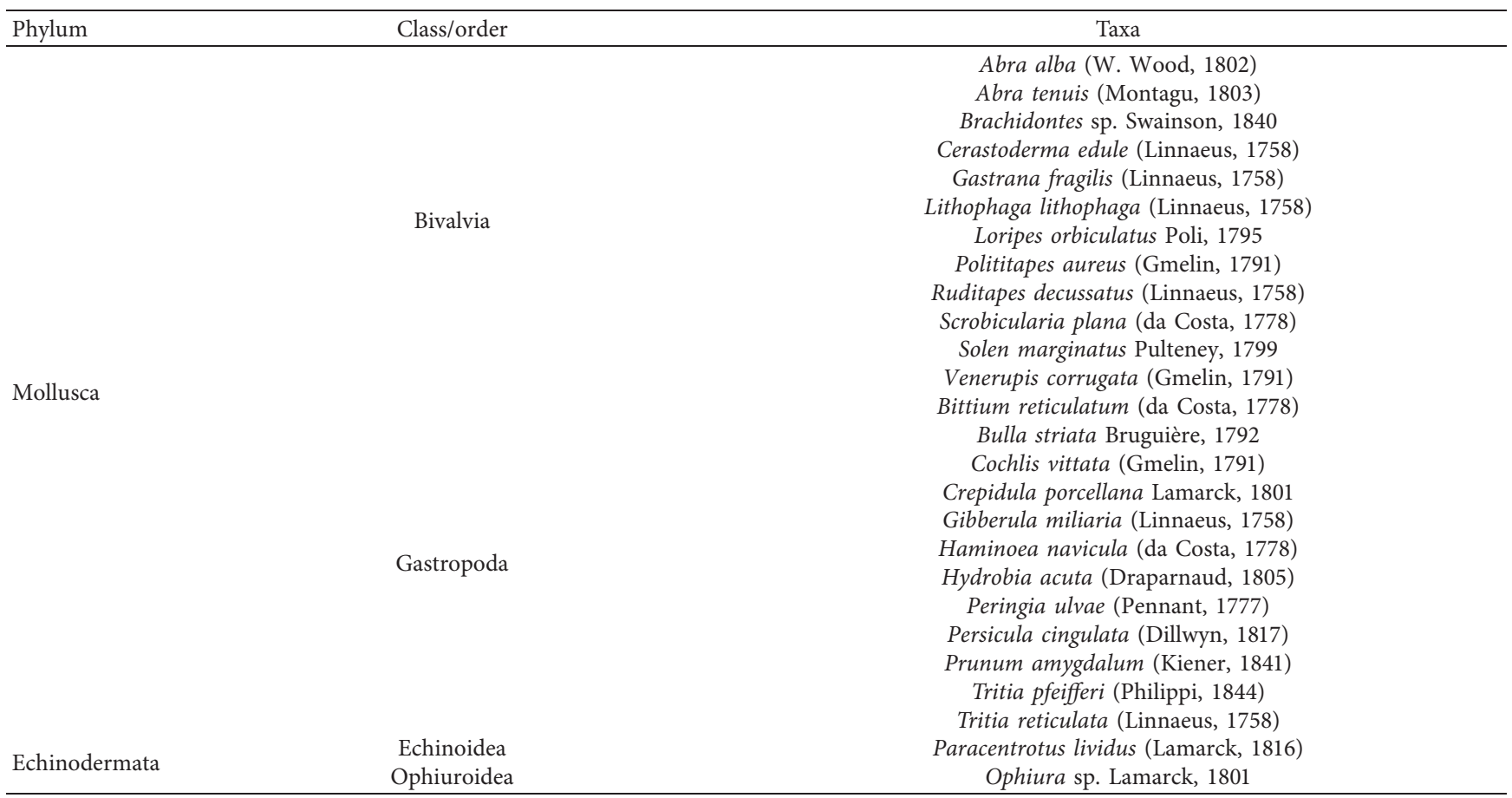

of continental freshwater inputs [35] which maintain the lagoon's generally good environmental quality [27].

\section{Conclusions}

Our study revealed broad-scale variability in species composition of benthic macrofauna associated to $Z$. noltei beds along the Atlantic coast of Morocco. The observed variability was influenced by seagrass biomass, which varied greatly crosswise sites. While such patterns could be related to ecological and biological factors such as habitat heterogeneity and traits of component species, regional and biogeographic factors such as climate and oceanographic current regimes may also be important although these variables were not tested directly in this study. The results of our study constitute as baseline data for planning the broadscale conservation of biodiversity in seagrass beds of Morocco, which remain suffering from multiple human-induced threats such as coastal developments and climate change.

\section{Data Availability}

Data used to support the findings of this work are available, upon request, from the corresponding author.

\section{Conflicts of Interest}

The authors declare that there are no conflicts of interest.

\section{Authors' Contributions}

Oussama Bououarour, Soilam Boutoumit, and Reda El Kamcha conducted investigation, curated data, wrote the original draft, and performed visualization and Hocein Bazairi conceptualized the study, formulated the methodology, wrote the original draft, reviewed and edited the manuscript, and supervised the work.

\section{Acknowledgments}

Dakhla and Khnifiss sampling (Southern Morocco) was funded by the "Centre des Etudes Sahariennes" (Project CES/2014-2016: Impact des changements climatiques globaux sur la biodiversité des zones humides sahariennes). The authors are grateful to Dr. Pierre Pouzet and Pr. Maanan Mohamed for their help in sediment laboratory analysis at the University of Nantes. Many thanks are given to those who contributed to the field and laboratory components of this work.

\section{References}

[1] C. R. Margules and R. L. Pressey, "Systematic conservation planning," Nature, vol. 405, no. 6783, pp. 243-253, 2000.

[2] S. E. Piacenza, A. K. Barner, C. E. Benkwitt et al., "Patterns and variation in benthic biodiversity in a large marine ecosystem," PLoS One, vol. 10, pp. 1-23, Article ID 0135135, 2015.

[3] I. Sanmartín, "Biogeography: an ecological and evolutionary approach," Systematic Biology, Wiley, vol. 55pp. 361-363, Hoboken, NJ, USA, 7th edition, 2006.

[4] N. L. Kinlock, L. Prowant, E. M. Herstoff et al., "Explaining global variation in the latitudinal diversity gradient: metaanalysis confirms known patterns and uncovers new ones," Global Ecology and Biogeography, vol. 27, pp. 125-141, 2018.

[5] J. C. Svenning and F. Skov, "Could the tree diversity pattern in Europe be generated by postglacial dispersal limitation?" Ecology Letters, vol. 10, pp. 453-460, 2007. 
[6] J. Hortal, J. A. F. Diniz-Filho, L. M. Bini et al., "Ice age climate, evolutionary constraints and diversity patterns of European dung beetles," Ecology Letters, vol. 14, pp. 741-748, 2011.

[7] L. Boyero, "Insect biodiversity in freshwater ecosystems: is there any latitudinal gradient?" Marine and Freshwater Research, vol. 53, pp. 753-755, 2002.

[8] L. B. Buckley and W. Jetz, "Environmental and historical constraints on global patterns of amphibian richness," Proceedings of the Royal Society B: Biological Sciences, vol. 274, pp. 1167-1173, 2007.

[9] K. J. Gaston, "Global patterns in biodiversity," Nature, vol. 405, pp. 220-227, 2000.

[10] B. Worm, M. Sandow, A. Oschlies, and H. K. Lotze, "Ecology: global patterns of predator diversity in the open oceans," Science, vol. 80, pp. 1365-1369, 2005.

[11] J. Soininen, J. J. Lennon, and H. Hillebrand, "A multivariate analysis of beta diversity across organisms and environments," Ecology, vol. 88, pp. 2830-2838, 2007.

[12] M. Spalding, M. Taylor, C. Ravilious, and F. T. Short, "Global over-view: the distribution and status of seagrasses," in World Atlas of Seagrasses, E. P. Green and F. T. Short, Eds., pp. 5-27, University of California Press, Berkley, CA, USA, 2003.

[13] J. E. Duffy, P. L. Reynolds, C. Boström et al., "Biodiversity mediates top-down control in eelgrass ecosystems: a global comparative-experimental approach," Ecology Letters, vol. 18, pp. 696-705, 2015.

[14] D. W. Klumpp and S. N. Kwak, "Composition and abundance of benthic macrofauna of a tropical sea-grass bed in North Queensland, Australia," Pacific Science, vol. 59, pp. 541-560, 2005.

[15] C. Boström, E. L. Jackson, and C. A. Simenstad, "Seagrass landscapes and their effects on associated fauna: a review," Estuarine, Coastal and Shelf Science, vol. 68, pp. 383-403, 2006.

[16] X. De Montaudouin and P.-G. Sauriau, "Contribution to a synopsis of marine species richness in the Pertuis Charentais Sea with new insights in soft-bottom macrofauna of the Marennes-Oleron Bay," Cahiers de Biologie Marine, vol. 41, pp. 181-222, 2000.

[17] M. R. Willig, D. M. Kaufman, and R. D. Stevens, "Latitudinal gradients of biodiversity: pattern, process, scale, and synthesis," Annual Review of Ecology, Evolution and Systematics, vol. 34, pp. 273-309, 2003.

[18] M. Nakaoka, K.-S. S. Lee, X. Huang et al., "Regional comparison of the ecosystem services from seagrass beds in Asia," Ecological Research Monographs, pp. 1-12, 2010.

[19] F. G. Brun, J. J. Vergara, G. Navarro, and I. Hernández, "Effect of shading by Ulva rigida canopies on growth and carbon balance of the seagrass Zostera noltii," Marine Ecology Progress Series, vol. 265, pp. 85-96, 2003.

[20] A. W. D. Larkum, R. J. Orth, and C. M. Duarte, "Seagrasses: biology, ecology and conservation," Seagrasses: Biology, Ecology and Conservation, Springer, Berlin, Germany, pp. 1-691, 2006.

[21] S. Hammada, Etudes sur la Végétation des Zones Humides du Maroc: Catalogue et Analyse de la Biodiversité Floristique et Identification es Principaux Groupement Végétaux, Université Mohammed V-Agdal, Faculté des Sciences, Rabat, Morocco, 2007.

[22] M. Waycott, C. M. Duarte, and T. J. B. Carruthers, “Accelerating loss of seagrasses across the globe threatens coastal ecosystems," Proceedings of the National Academy of Sciences, vol. 106, pp. 12377-12381, 2009.
[23] M. A. Hemminga and C. M. Duarte, Seagrass Ecology, Cambridge University Press, vol. 71, pp. 79-80, , Cambridge, UK, 2000.

[24] S. Cabaço, R. Santos, and M. Sprung, "Population dynamics and production of the seagrass Zostera noltii in colonizing versus established meadows," Marine Ecology, vol. 33, pp. 280-289, 2012.

[25] F. Touhami, H. Bazairi, B. Badaoui, and A. Benhoussa, "The impact of wader predation on benthic macrofauna in Merja Zerga Lagoon, Morocco: an exclosure experiment," Wader Study, vol. 124, pp. 225-237, 2017.

[26] F. El Asri, D. Martin, A. Errhif, and N. Tamsouri, "Community structure and spatial patterns of soft-bottom macrozoobenthos in Oualidia Lagoon, Moroccan Atlantic," Thalassas: An International Journal of Marine Sciences, vol. 37 , no. 4, pp. 1-11, 2020.

[27] L. Lefrere, M. Ouassas, B. Guillois, and P. Gillet, "Macrobenthic community structure of soft-bottom sediments in the Khnifiss Lagoon, South of Morocco," Journal of Materials and Environmental Science, vol. 6, pp. 3226-3235, 2015.

[28] H. Bazairi, A. Bayed, M. Glémarec, and C. Hily, "Spatial organisation of macrozoobenthic communities in response to environmental factors in a coastal lagoon of the NW African coast (Merja Zerga, Morocco)," Oceanologica Acta, vol. 26, pp. 457-471, 2003.

[29] A. Mhamdi Alaoui, M. Choura, M. Maanan, and B. Zourarah, "Metal fluxes to the sediments of the Moulay Bousselham lagoon, Morocco," Environmental Earth Sciences, vol. 61, pp. 275-286, 2010.

[30] K. Hilmi, A. Orbi, J. Lakhdar Idrissi, F. Sarf, and M. Chagdali, "Etude courantologique descriptive de la lagune de sidi moussa (printemps 1997)," in Proceeding of Colloquia on Marine Hydrodynamics, School of Science Ben M'Sik, Casablanca, Morocco, 2000.

[31] M. Maanan, "Heavy metal concentrations in marine molluscs from the Moroccan coastal region," Environmental Pollution, vol. 153, pp. 176-183, 2008.

[32] K. Hilmi, V. G. Koutitonsky, A. Orbi, J. Lakhdar, and M. Chagdali, "Oualidia lagoon, Morocco: an estuary without a river," African Journal of Aquatic Science, vol. 30, pp. 1-10, 2005.

[33] M. Maanan, A. C. Ruiz-Fernández, M. Maanan, and F. Paul, "A long-term record of land use change impacts on sediments in Oualidia Lagoon, Morocco," International Journal of Sediment Research, vol. 29, pp. 1-10, 2014.

[34] P. Beaubrun, M. Thevenot, and J. Schouten, "Wintering and summering water bird population in the Khnifiss Lagoon [Morocco]," Travaux de l'Institut Scientifique, pp. 125-139, 1988.

[35] J. Lakhdar Idrissi, A. Orbi, and F. Zidane, "Organization and functioning of a Moroccan ecosystem: Khnifiss Lagoon," Journal of Water Science, vol. 17, pp. 447-462, 2004.

[36] K. Hilmi, A. Orbi, A. Makaoui et al., "Circulation marine de La baie de Dakhla (sud du maroc) par modèle hydrodynamique 2D," European Scientific Journal, vol. 13, pp. 68-82, 2017.

[37] Z. Saad, A. Orbi, R. Abouabdellah, A. Saad, and B. Oudra, "Impact of economic development on the dynamics of phytoplankton and physic-chemical quality of Dakhla Bay (South of Morocco)," South Asian Journal of Experimental Biology, vol. 3, pp. 274-287, 2013.

[38] C. K. Wentworth, "A scale of grade and class terms for clastic sediments author," The Journal of Geology, vol. 30, pp. 377-392, 1922. 
[39] S. J. Blott and K. Pye, "GRADISTAT: a grain size distribution and statistics package for the analysis of unconsolidated sediments," Earth Surface Processes and Landforms, vol. 26, pp. 1237-1248, 2001.

[40] P. Pouzet and M. Maanan, "Temporal approaches of historical extreme storm events based on sedimentological archives," Journal of African Earth Sciences, vol. 162, Article ID 103710, 2020.

[41] J. E. Andrews, G. Samways, and G. B. Shimmield, "Historical storage budgets of organic carbon, nutrient and contaminant elements in saltmarsh sediments: biogeochemical context for managed realignment, Humber Estuary, UK," The Science of the Total Environment, vol. 405, pp. 1-13, 2008.

[42] G. J. Michaelson, C. L. Ping, and M. T. Jorgenson, "Methane and carbon dioxide content in eroding permafrost soils along the Beaufort Sea coast, Alaska," Journal of Geophysical Research: Biogeosciences, vol. 116, 2011.

[43] K. R. Clarke and R. M. Warwick, Change in Marine Communities: An Approach to Statistical Analysis and Interpretation, PRIMER-e, Plymouth, UK, 2nd edition, 2001.

[44] M. J. Anderson and T. J. Willis, "Canonical analysis of principal coordinates: a useful method of constrained ordination for ecology," Ecology, vol. 84, pp. 511-525, 2003.

[45] M. J. Anderson, R. N. Gorley, and K. R. Clarke, PERMANOVA+ for PRIMER: Guide to Software and Statistical Methods, PRIMER-e, Plymouth, UK, 2008.

[46] K. R. Clarke and R. M. Warwick, "A further biodiversity index applicable to species lists: variation in taxonomic distinctness," Marine Ecology Progress Series, vol. 216, pp. 265-278, 2001.

[47] M. J. Anderson, “Animal-sediment relationships re-visited: characterising species' distributions along an environmental gradient using canonical analysis and quantile regression splines," Journal of Experimental Marine Biology and Ecology, vol. 366, pp. 16-27, 2008.

[48] S. Thrush, P. Dayton, R. Cattaneo-Vietti et al., "Broad-scale factors influencing the biodiversity of coastal benthic communities of the Ross Sea," Deep Sea Research Part II: Topical Studies in Oceanography, vol. 53, pp. 959-971, 2006.

[49] B. K. Walker, "Spatial analyses of benthic habitats to define coral reef ecosystem regions and potential biogeographic boundaries along a latitudinal gradient," PLoS One, vol. 7, Article ID 0030466, 2012.

[50] C. A. Blanchette, C. Melissa Miner, P. T. Raimondi, D. Lohse, K. E. K. Heady, and B. R. Broitman, "Biogeographical patterns of rocky intertidal communities along the Pacific coast of North America," Journal of Biogeography, vol. 35, pp. 15931607, 2008.

[51] A. L. Freestone and R. W. Osman, "Latitudinal variation in local interactions and regional enrichment shape patterns of marine community diversity," Ecology, vol. 92, pp. 208-217, 2011.

[52] P. Miloslavich, E. Klein, J. M. Díaz et al., "Marine biodiversity in the Atlantic and pacific coasts of South America: knowledge and gaps," PLoS One, vol. 6, Article ID 0014631, 2011.

[53] S. Boutoumit, R. El Kamcha, O. Bououarour et al., "Softbottom macrozoobenthos in semi-enclosed coastal systems of Morocco: a latitudinal and biogeographic analysis," Regional Studies in Marine Science, vol. 44, Article ID 101689, 2021.

[54] E. V. J. Tanner, "Edge effects on fauna in fragmented seagrass meadows," Austral Ecology, vol. 30, pp. 210-218, 2005.

[55] N. Mosbahi, H. Blanchet, N. Lavesque, X. de Montaudouin, J.-C. Dauvin, and L. Neifar, "Main ecological features of benthic macrofauna in mediterranean and Atlantic intertidal eelgrass beds: a comparative study," Journal of Marine Biology \& Oceanography, vol. 6, 2017.

[56] K. Reise, E. Herre, and M. Sturm, "Biomass and abundance of macrofauna in intertidal sediments of Königshafen in the northern Wadden Sea," Helgolaender Meeresuntersuchungen, vol. 48, pp. 201-215, 1994.

[57] M. Dornelas, N. J. Gotelli, B. McGill et al., "Assemblage time series reveal biodiversity change but not systematic loss," Science, vol. 80, pp. 296-299, 2014.

[58] A. Clarke and S. Lidgard, "Spatial patterns of diversity in the sea: bryozoan species richness the North Atlantic," Journal of Animal Ecology, vol. 69, pp. 799-814, 2000.

[59] K. Roy, D. Jablonski, and J. W. Valentine, "Dissecting latitudinal diversity gradients: functional groups and clades of marine bivalves," Proceedings of the Royal Society B: Biological Sciences, vol. 267, pp. 293-299, 2000.

[60] N. Bonada, S. Dolédec, and B. Statzner, "Taxonomic and biological trait differences of stream macroinvertebrate communities between mediterranean and temperate regions: implications for future climatic scenarios," Global Change Biology, vol. 13, pp. 1658-1671, 2007.

[61] C. Möllmann and R. Diekmann, "Marine ecosystem regime shifts induced by climate and overfishing. A review for the northern hemisphere," Advances in Ecological Research, vol. 47, pp. 303-347, 2012.

[62] R. A. Chisholm, M. A. Burgman, S. P. Hubbell, and L. BordaDe-Água, The Unified Neutral Theory of Biodiversity and Biogeography: Comment, Princeton University Press, Princeton, NJ, USA, 2004.

[63] A. Basset and M. Abbiati, "Challenges to transitional water monitoring: ecological descriptors and scales," Aquatic Conservation: Marine and Freshwater Ecosystems, vol. 14, pp. 1-3, 2004.

[64] R. MacArthur, "Species packing and competitive equilibrium for many species," Theoretical Population Biology, vol. 1, pp. 1-11, 1970.

[65] O. Bououarour, R. El Kamcha, S. Boutoumit, P. Pouzet, M. Maanan, and H. Bazairi, "Effects of the Zostera noltei meadows on benthic macrofauna in North Atlantic coastal ecosystems of Morocco: spatial and seasonal patterns," Biologia, vol. 76, pp. 2263-2275, 2021.

[66] A. W. Stoner, "The role of seagrass biomass in the organization of benthic macrofaunal assemblages," Bulletin of Marine Science, vol. 30, pp. 537-551, 1980.

[67] E. González-Ortegón, F. Baldó, A. Arias et al., "Freshwater scarcity effects on the aquatic macrofauna of a European Mediterranean-climate estuary," The Science of the Total Environment, vol. 503-504, pp. 213-221, 2015.

[68] L. Boutahar, M. Maanan, O. Bououarour et al., "Biomonitoring environmental status in semi-enclosed coastal ecosystems using Zotera noltei meadows," Ecological Indicators, vol. 4, pp. 75-84, 2019.

[69] P. E. Renaud, T. J. Webb, and A. Bjørgesaeter, "Continentalscale patterns in benthic invertebrate diversity: insights from the MacroBen database," Marine Ecology Progress Series, vol. 382, pp. 239-252, 2009. 